\title{
Arsenic in soil, vegetation and water of a contaminated region
}

\author{
${ }^{1}$ S. Zandsalimi; ${ }^{2 * N}$. Karimi; ${ }^{3}$ A. Kohandel \\ ${ }^{1}$ Iranian Academic Center for Education Culture and Research, Sanandaj, Kurdistan, Iran \\ ${ }^{2}$ Laboratory of plant physiology, Department of Biology, Faculty of Science, Razi University, Kermanshah, Iran \\ ${ }^{3}$ Iranian Academic Center for Education Culture and Research, Tehran, Iran
}

Received 16 March 2010; $\quad$ revised 11 January 2011; accepted 25 February 2011; $\quad$ available online 1 March 2011

\begin{abstract}
Arsenic concentrations of surface waters, soils and plants were surveyed in three contaminated villages of Bijar County. Total arsenic in water samples (4.5 to $280 \mu \mathrm{g} / \mathrm{L})$ was correlated with electrical conductivity, total dissolved solid, total hardness, alkalinity, chloride, sulphate, bicarbonate, calcium and sodium $(\mathrm{p}<0.001)$. Total arsenic in the soils ranged from 105.4 to $1500 \mathrm{mg} / \mathrm{kg}$. Some of the soil factors play an important role in soil arsenic content and its bioavailability for organisms. In general, the arsenic concentrations in plants were low, especially in the most common wild species. Among 13 plant species, the highest mean arsenic concentration was found in leaves of Mentha Longifolia $(79.4 \mathrm{mg} / \mathrm{kg})$. Arsenic levels in soils and plants were positively correlated, while the ability of the plants to accumulate the element, expressed by their biological accumulation coefficients and arsenic transfer factors, was independent of the soil arsenic concentration. Relationships between the arsenic concentrations in plants, soils and surface water and the environmental aspects of these relationships have been discussed in comparison with literature data. The accumulation of arsenic in environmental samples (soil, sediment, water, plant, etc.) poses a potential risk to human health due to the transfer of this element in aquatic media, their uptake by plants and subsequent introduction into the food chain.
\end{abstract}

Keywords: Arsenic contamination; Arsenic transfer coefficient; Biological accumulation factor; Groundwater

\section{INTRODUCTION}

Arsenic can be found naturally on earth in small concentration. It occurs in soil and minerals and it may enter air, water and land and uptake by plants (Mahzuz et al., 2009; Reza and Singh, 2010). Plants vary considerably in their tolerance of arsenic and in the amount of arsenic that they can take up from soils and water (Goyal et al., 2008; Feng et al., 2009; Malakootian et al., 2009; Urik et al., 2009). Arsenic is a naturally occurring element present in the both inorganic and organic forms in different environmental and biological samples and its concentrations may be increased by anthropogenic contamination (Villa-Lojo et al., 2002). Arsenic presence in water has been reported from several parts of the world, like USA, China, Chile, Bangladesh, Taiwan, Mexico, Argentina, Poland, Canada, Hungary, Japan, India, Vietnam, Nepal (Jain and Ali, 2000; Jack et al., 2003) and recently from Iran (Mosaferi et al., 2003). Inorganic As is considered

\section{《*Corresponding Author Email: nkarimie@yahoo.com}

Tel: +98831 8211 869; Fax: +98831 4274545 to be the major form of As in groundwater, surface water, soil and various foods (Babel and Opiso, 2007) and have been classified as group I carcinogens based on human epidemiological data (Hughes, 2002). Millions of people have been exposed to arsenic contamination through drinking water. In some regions of Pakistan, drinking water comes from groundwater and surface water, including rivers, lakes and reservoirs (Duker et al., 2005). The present free style way of disposing agricultural, industrial and domestic effluents into natural water-bodies results in serious surface and groundwater contamination (Abdel-Ghani and Elchaghaby, 2007;Okafor and Opuene, 2007; Samarghandi et al., 2007; Abdel-Ghani et al., 2009; Karimi et al., 2010). Run-off from agricultural and saline seeps subject the most vulnerable water bodies to pollution and increased salinity, so the freshwater lakes are highly impacted. Arsenic contaminated groundwater is not only used as a source of drinking water, but also 
extensively used for irrigation in some regions. Uptake of As by plants depends on the physicochemical make up of the plant species and soil. The concentration of arsenic in cereals, vegetables and fruits is directly related to the level of arsenic in the soil (Kazia et al., 2009). Severe arsenic contamination of soils may cause arsenic toxicity in plants, animals and human (Warren et al., 2003). Remediation of arsenic contaminated soils has thus become a major environmental issue. Kurdistan, a western province of Iran, is facing the problem of arsenic con-tamination. In the northeast of the province, there are some villages in Bijar County where drinking water has been contaminated with naturally occurring arsenic. Widespread water and crop contamination in these areas are originating from the natural release of arsenic through aquifer and sedimentary rocks. Also, this element is a fundamental constituent of the sulfide mineral arsenopyrite (FeAsS), as well as the minerals lingite (FeAs), realgar (AsS) and orpiment $\left(\mathrm{As}_{2} \mathrm{~S}_{3}\right)$; (Karimi et al., 2010). In some villages the arsenic in water supplies, exceeds $1,000 \mu \mathrm{g} / \mathrm{L}$ with an average con-centration of $290 \mu \mathrm{g} / \mathrm{L}$ (Mosaferi et al., 2009). Chronic poisoning manifestations, such as skin lesions: keratosis, pigmentationl and even amputation due to gangrene, have been reported. Despite many studies on the occurrence of arsenic in drinking water in Bijar county and the resulting poisoning of the inhabitants (Mosaferi et al., 2003, 2005 and 2009), there is no information on the arsenic concentrations in soil and plant species and on the arsenic bioaccumulation potential of plant species indigenous to this area. Therefore, the present study has been performed with the following objectives: (1) to determine the As concentrations in water, soil and leaves of plants growing in contaminated areas to explore the degrees of environmental contamination; (2) to assess the potential risk of environmental arsenic in the Bijar area and (3) to correlate the As concentrations in ground water soil and plants. To do so, three villages located in highly Ascontaminated areas in Bijar County were examined from May to October 2008.

\section{MATERIALS AND METHODS}

Study area

Kurdistan province is located in the West of Iran, bordering Iraq from $34^{\circ} 442$ to $36^{\circ} 302$ North, and, $45^{\circ}$ 312 to $48^{\circ} 162$ East (Fig. 1). This province is one of the most mountainous provinces of Iran and has a generally cold climate. Kurdistan province represents about $1.7 \%$ of the area of the entire country and has more than, 450,000 inhabitants. In the Northeast of the province, there are some villages in Bijar County (a $580-\mathrm{km}^{2}$ area with an average altitude of about $1750 \mathrm{~m}$ above sea level) where drinking water has been contaminated with naturally-occurring arsenic (Mosaferi et al., 2005). In addition to Bijar, the region of Ghorveh has also faced a similar problem (Mosaferi et al., 2003).

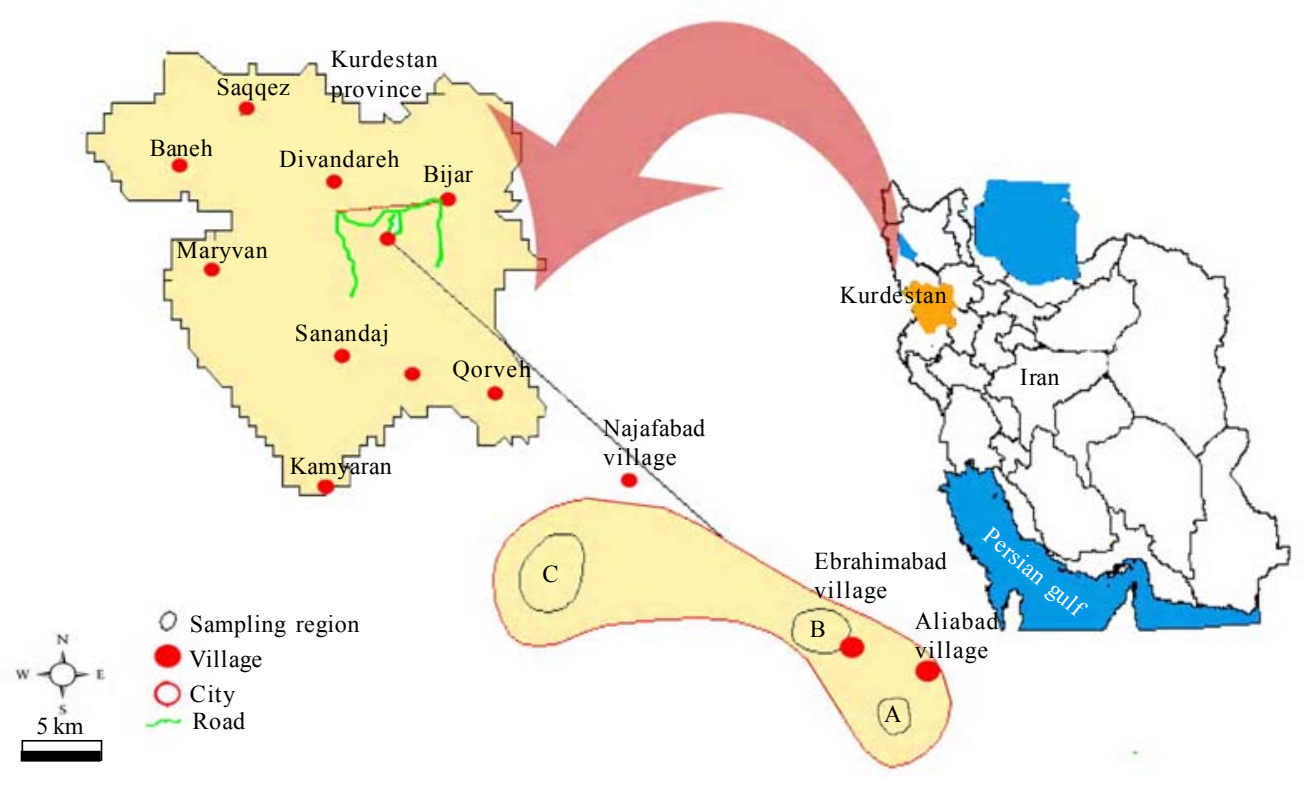

Fig. 1: Location of the study area in Bijar County, Iran 
The present study was carried out in three contaminated villages of Bijar County. These villages were selected on the basis of the high arsenic contamination and the inadequate supply of safe drinking water (Mosaferi et al., 2009). These are Aliabad, Ebrahimabad and Najafabad and their positions are shown in Fig. 1.

\section{Surface water sampling and analysis}

Shallow wells for sampling were selected based on a previous study regarding arsenic occurrence in drinking water of the Kurdistan province (Mosaferi et al., 2003). Water samples were collected from the most contaminated shallow wells used for agricultural irrigation (one well per village). Water samples were filtered through a $0.45 \mu \mathrm{m}$ membrane filter and divided into two portions. One portion was acidified with $\mathrm{HNO}_{3}(0.2 \% \mathrm{v} / \mathrm{v})$ for the analysis of As concentrations, while the other was left un-acidified for $\mathrm{pH}$, electrical conductivity(EC), total dissolved solid (TDS) and total hardness $(\mathrm{TH})$ measurements. Water samples were stored in a refrigerator at $4{ }^{\circ} \mathrm{C}$ to prevent changes due to chemical or biological activity as well as loss due to evaporation. The analyses of water samples represented the total load of arsenic (dissolved plus colloid bound) in the water samples. Physical parameters like $\mathrm{pH}$, TDS and EC were determined by a portable combine meter (Milwaukee, model SM802) and TH was measured by the following equation: $\mathrm{TH}=2.497 \mathrm{Ca}+4.115 \mathrm{mg}$ (Vasanthavigar et al., 2010). The major cations and anions including sodium, potassium, calcium, magnesium, chloride, bicarbonate and nitrate were determined according to standard specifications prescribed by APHA et al., (1992). The samples were analyzed for arsenic using hydride generation atomic absorption spectrometry with a flow injection hydride generator. Standard materials for chemical analysis were purchased from Merck and the calibration curve fit (at least five standard concentrations) was of $\mathrm{R}^{2}>0.97$ in all cases. The method's recovery of As $(0.79 \pm 0.08 \mathrm{mg} / \mathrm{kg})$ from certified reference material (Beach leaves material FD8, Commission of the European Communities, Joint Research Centre ISPRA) was not significantly different from the certified reference value $(0.76 \pm 0.1 \mathrm{mg} / \mathrm{kg})$. The mean As concentration in blank digests was $0.08 \mu \mathrm{g} / \mathrm{L}$ and the detection limit for As in plant tissue was $0.05 \mu \mathrm{g} /$ L.

\section{Soil sampling}

Soil was collected during the period of sampling from three As-contaminated areas (18 samples per each area). The soil samples were taken in three different ways. First, surface soil samples were collected at different distance
$(0,400$ and $800 \mathrm{~m})$ from the contaminated shallow well of each village to determine the extent of As contamination. Second, samples were taken from different depth (surface and subsurface). Third, soil attached to plant roots (rhizosphere soil) was sampled to determine the bioaccumulation factor of each plant species collected from the study areas.

\section{Soil characteristics}

Soil properties were determined as follows: $\mathrm{pH}$ was determined potentiometrically in a soil paste saturated with water and organic matter was determined by dichromate oxidation using the Tiurin method (Soon and Abboud, 1991). Total soil phosphorus (P) was measured by the Olsen method (Olsen et al., 1954). The particle size distribution (sand, silt and clay) was analyzed by the hydrometer method (Ashworth et al., 2001).

\section{Soil arsenic analysis}

A portion of each sample (about $5 \mathrm{~g}$ ) was spread to remove roots and external contaminants, air-dried and oven-dried at $80 \pm 5^{\circ} \mathrm{C}$ for $12 \mathrm{~h}$ and ground to fine powder with an agate mortar and preserved in desiccators for subsequent analysis. For total As analysis, soil samples $(0.5 \mathrm{~g})$ were transferred to a Kjeldahl digestion tube for extraction with $10 \mathrm{ml}$ of a $3: 1 \mathrm{HCl} / \mathrm{HNO}_{3}$ mixture. Tubes were left overnight at room temperature and then placed in a heating block. After cooling, the digests were filtered through a moistened Whatman No. 40 filter paper and made up to $50 \mathrm{~mL}$ volume with distilled water. The digest was analyzed for arsenic using hydride generation-atomic absorption spectrometry as described above.

\section{Plant sampling and analysis}

The plant samples were taken from the same location as the soil samples. Only plant species which were found frequently in the study areas and/or had a high shoot biomass were collected. A total of 46 plant samples belonging to 13 different species were collected. Only the aerial parts of the plants (stems, branches and leaves) were collected; the roots were not sampled to avoid contamination with adhering soil material. Plant samples were washed with tap water, rinsed with deionized water and oven-dried at 50 - 55ÚC for $72 \mathrm{~h}$. They were digested as described by Meharg and Jardin (2003). Analysis of As was performed by atomic absorption spectrophotometry, as described above. 


\section{RESULTS AND DISCUSSION}

Arsenic in surface water

Table 1 shows the characteristics of the shallow wells used for irrigation in the villages studied. The characteristics were different and considering hardness, the water sources were classified into hard or very hard water (total hardness $>150 \mathrm{mg} / \mathrm{L}$ as $\mathrm{CaCO}_{3}$ ). The highest levels of hardness and TDS were observed in Aliabad, while in Najafabad the levels were the lowest. Except for arsenic, the concentrations of heavy metals were lower than the WHO guideline levels. All the shallow wells sampled in this study, had arsenic concentrations higher than the WHO drinking water standard of $10 \mu \mathrm{g} / \mathrm{L}$. The electrical conductivity (EC) of the surface water varied from 500 to $927 \mathrm{ds} / \mathrm{m}$ with $\mathrm{pH} 7.38$ to 7.72 , indicating that TDS in water is within the limit. There were significant correlations between arsenic levels and EC, TDS, TH, alkalinity, chloride, sulphate, bicarbonate, calcium and sodium of analyzed waters $(\mathrm{p}<0.001)$ (Table 1$)$. The highest correlation was observed between arsenic and TDS $(\mathrm{R}=0.867)$. The As concentration of the Aliabad shallow well was higher than $1200 \mu \mathrm{g} / \mathrm{L}$, i.e. more than 120 times higher than the WHO drinking water standard of $10 \mu \mathrm{g} / \mathrm{L}$.

\section{Soil characteristics}

The $\mathrm{pH}$, organic matter and soil texture of each site, together with the total As concentrations, are given in Table 2. The pH was neutral in area A and area B, while it was alkaline area $\mathrm{C}$. All the sampling sites showed very low levels of $\mathrm{P}$ in the soil. The soil texture analysis revealed significant differences between sites, particularly with regard to the silt and clay fractions. In area B the silt content was much higher than that of clay, whereas the opposite pattern was found in area A (Table 2). Total soil $\mathrm{P}$ at each sampling site was within the range normally encountered in soils $(4.5-28 \mathrm{mg} / \mathrm{kg})$ and showed no significant differences between sites.

\section{Arsenic in soil}

The highest soil As concentrations were found in the area around the shallow well in Ebrahimabad (area B; Table
2). In general, the soil arsenic concentrations in area $A$ and $B$ were much higher than the average toxicity threshold of $40 \mathrm{mg} / \mathrm{kg}$ established for crop plants as reported by Sheppard (1992). The mean As concentration in Najafabad was much lower than in Aliabad and Ebrahimabad (Table 2). The As concentrations of $0-20 \mathrm{~cm}$ and the $20-40 \mathrm{~cm}$ soil layers were comparable and there was no consistent decrease of the soil As concentration with increasing distance from the well (Table 2).

\section{Arsenic in plants}

A total of 13 plant species belonging to 11 families were sampled (Table 3). In area C, plants showed very low As concentrations, occasionally below the limit of instrumental detection (Table 3). Only 2 species, among which Mentha longifolia, had As concentration above the normal range of $0.1-0.5 \mathrm{mg} / \mathrm{kg}$ (Lombi and Nolan, 2005). In the B area, plants had much higher As concentration, usually above $5 \mathrm{mg} / \mathrm{kg}$ (10 out of 13 ), but only Mentha longifolia showed considerable accumulation, with $86.25 \mathrm{mg} / \mathrm{kg}$ of As in its leaves (Table 2). Of the 13 plant species sampled in area $A 8$ had more than $10 \mathrm{mg} / \mathrm{kg}$ of arsenic in their leaves, again with Mentha longifolia as the best As accumulator (79.34 mg/kg).

Relationship between the As concentrations in surface soils and surface water

The As concentration ranged from 180 to $1500 \mathrm{mg} / \mathrm{kg}$ in surface soil and from 4.5 to $1280 \mu \mathrm{g} / \mathrm{L}$ in surface water. The As concentration of surface soil tended to increase with the As concentration of the surface water with linear regression coefficients of $0.371(\mathrm{P}<0.001)$, $0.221(\mathrm{P}<0.001)$ and $0.026(\mathrm{P}<0.01)$, for Aliabad, Ebrahimabad and Najafabad respectively.

Relationship between the As concentrations in plant leaves and surface soils

There is a relationship between As concentrations of plant leaves and surface soils at the three studied sites in Bijar county (Fig. 2). Overall, shoot As concentrations increased more or less linearly with total

Table 1: Analysis of local surface water sources from three contaminated areas in Bijar County

\begin{tabular}{|c|c|c|c|c|c|c|c|c|c|c|c|c|c|}
\hline Location & $\begin{array}{c}\text { As } \\
(\mu \mathrm{g} / \mathrm{L})\end{array}$ & $\begin{array}{c}\mathrm{K} \\
(\mathrm{meq} / \mathrm{L})\end{array}$ & $\begin{array}{c}\mathrm{Na} \\
(\mathrm{meq} / \mathrm{L})\end{array}$ & $\begin{array}{c}\mathrm{Ca} \\
(\mathrm{meq} / \mathrm{L})\end{array}$ & $\begin{array}{c}\mathrm{mg} \\
(\mathrm{meq} / \mathrm{L})\end{array}$ & $\begin{array}{c}\mathrm{HCO}_{3} \\
(\mathrm{meq} / \mathrm{L})\end{array}$ & $\begin{array}{c}\mathrm{Cl} \\
(\mathrm{meq} / \mathrm{L})\end{array}$ & $\begin{array}{c}\mathrm{NO}_{3} \\
(\mathrm{meq} / \mathrm{L})\end{array}$ & $\begin{array}{c}\mathrm{EC} \\
(\mathrm{ds} / \mathrm{m})\end{array}$ & $\mathrm{pH}$ & $\begin{array}{c}\text { TDS } \\
(\mathrm{mg} / \mathrm{L})\end{array}$ & SAR & $\begin{array}{c}\text { Hardness } \\
\left(\mathrm{mg} / \mathrm{L} \mathrm{CaCO}_{3}\right)\end{array}$ \\
\hline $\begin{array}{l}\text { Aliabad } \\
\text { (Area A) }\end{array}$ & 1280.56 & 0.065 & 0.221 & 1.832 & 7.896 & 5.723 & 0.35 & 0.09 & 750.12 & 7.38 & 553.23 & 0.09 & 192.52 \\
\hline $\begin{array}{l}\text { Ebrahimabad } \\
\text { (Area B) }\end{array}$ & 400.89 & 0.155 & 0.521 & 1.712 & 6.121 & 5.865 & 1.14 & 0.13 & 927.56 & 7.72 & 434.85 & 0.02 & 156.96 \\
\hline $\begin{array}{l}\text { Najafabad } \\
\text { (Area C) }\end{array}$ & 4.53 & 0.012 & 0.027 & 3.521 & 2.512 & 3.645 & 1.92 & 0.26 & 500.32 & 7.58 & 302.63 & 0.26 & 120.46 \\
\hline
\end{tabular}


Int. J. Environ. Sci. Tech., 8 (2), 331-338, Spring 2011

Table 2: Arsenic concentration and some edaphic parameters in the three contaminated areas in Bijar County

\begin{tabular}{|c|c|c|c|c|c|c|c|c|c|c|}
\hline \multirow[t]{2}{*}{ Location } & \multirow[t]{2}{*}{ Block } & \multicolumn{2}{|c|}{ Total As in soil samples $(\mathrm{mg} / \mathrm{kg})$} & \multicolumn{3}{|c|}{ Soil texture $(\%)$} & \multirow[t]{2}{*}{$\mathrm{pH}$} & \multirow{2}{*}{$\begin{array}{c}\text { EC } \\
(\mathrm{ds} / \mathrm{m})\end{array}$} & \multirow{2}{*}{$\begin{array}{c}\text { O.M } \\
(\mathrm{mg} / \mathrm{kg})\end{array}$} & \multirow{2}{*}{$\begin{array}{c}\text { Total P } \\
(\mathrm{mg} / \mathrm{kg})\end{array}$} \\
\hline & & $0-20$ & $20-40$ & Sand & Silt & Clay & & & & \\
\hline Aliabad & $\begin{array}{c}0 \\
400 \mathrm{~m} \\
800 \mathrm{~m}\end{array}$ & $\begin{array}{r}1300.36^{*} \pm 365.23 \\
1180 \pm 211.56 \\
875.63 \pm 98.65\end{array}$ & $\begin{array}{l}1670.56 \\
1000.54 \\
1250.05\end{array}$ & $\begin{array}{l}48.21 \\
59.52 \\
52.12\end{array}$ & $\begin{array}{l}21.02 \\
18.01 \\
25.11\end{array}$ & $\begin{array}{l}26.01 \\
23.06 \\
32.32\end{array}$ & $\begin{array}{l}7.11 \\
7.59 \\
7.69\end{array}$ & $\begin{array}{l}1.177 \\
1.596 \\
0.89\end{array}$ & $\begin{array}{c}1.12 \\
0.965 \\
1.32\end{array}$ & $\begin{array}{l}28.21 \\
13.02 \\
15.98\end{array}$ \\
\hline Ebrahimabad & $\begin{array}{c}0 \\
400 \mathrm{~m} \\
800 \mathrm{~m}\end{array}$ & $\begin{array}{l}1500.00 \pm 101.87 \\
1050.11 \pm 113.52 \\
1250.63 \pm 275.63\end{array}$ & $\begin{array}{l}1100.32 \\
1150.87 \\
1400.56\end{array}$ & $\begin{array}{l}60.25 \\
57.32 \\
53.23\end{array}$ & $\begin{array}{l}42.32 \\
33.23 \\
36.17\end{array}$ & $\begin{array}{c}9.12 \\
10.15 \\
14.45\end{array}$ & $\begin{array}{l}7.82 \\
7.89 \\
7.69\end{array}$ & $\begin{array}{l}0.72 \\
0.92 \\
2.67\end{array}$ & $\begin{array}{l}3.02 \\
2.17 \\
2.32\end{array}$ & $\begin{array}{l}13.25 \\
14.86 \\
25.87\end{array}$ \\
\hline Najafabad & $\begin{array}{c}0 \\
400 \mathrm{~m} \\
800 \mathrm{~m}\end{array}$ & $\begin{array}{l}250.56 \pm 21.32 \\
180.87 \pm 15.56 \\
270.25 \pm 20.52\end{array}$ & $\begin{array}{l}105.45 \\
190.32 \\
211.12\end{array}$ & $\begin{array}{l}47.11 \\
55.12 \\
53.52\end{array}$ & $\begin{array}{l}19.03 \\
25.04 \\
21.32\end{array}$ & $\begin{array}{l}23.45 \\
20.52 \\
29.52\end{array}$ & $\begin{array}{l}8.25 \\
8.15 \\
8.32\end{array}$ & $\begin{array}{l}0.85 \\
1.05 \\
2.20\end{array}$ & $\begin{array}{l}1.56 \\
1.62 \\
1.89\end{array}$ & $\begin{array}{c}5.81 \\
4.53 \\
10.02\end{array}$ \\
\hline
\end{tabular}

$*$ Mean $\pm \mathrm{SE}$

Table 3: Arsenic concentration in leaf samples collected from three contaminated areas in Bijar County

\begin{tabular}{|c|c|c|c|c|c|}
\hline \multirow{2}{*}{ Family } & \multirow{2}{*}{ Scientific Name } & \multirow{2}{*}{ No. sample } & \multicolumn{3}{|c|}{ Total As (mg/kg) } \\
\hline & & & $\mathrm{A}$ & $\mathrm{B}$ & $\mathrm{C}$ \\
\hline Apiaceae & Falcaria scioidesAsch. & 2 & $2.62 \pm 0.3$ & $9.03 \pm 0.6$ & $0.30 \pm 0.01$ \\
\hline Asteraceae & Achillea millefolium & 6 & $2.31 \pm 0.2$ & $21.41 \pm 1.6$ & $0.52 \pm 0.03$ \\
\hline Brassicaceae & Cardaria draba & 5 & $4.41 \pm 0.05$ & $21.32 \pm 2.1$ & ND \\
\hline Brassicaceae & Descurainia sophia & 3 & $2.65 \pm 0.4$ & $4.61 \pm 0.6$ & ND \\
\hline Chenopodiaceae & Chenopodium album & 8 & $25.00 \pm 4.3$ & $15.64 \pm 0.2$ & $10.41 \pm 1.3$ \\
\hline Euphorbiaceae & Euphorbia spp. & 2 & $3.58 \pm 0.8$ & $10.11 \pm 0.3$ & $0.24 \pm 0.02$ \\
\hline Fabaceae & Astragalus spp & 9 & $29.62 \pm 2.4$ & $23.31 \pm 2.1$ & $4.05 \pm 0.03$ \\
\hline Fabaceae & Medicago sativa & 2 & $29.61 \pm 2.1$ & $23.30 \pm 2.1$ & $4.05 \pm 0.06$ \\
\hline Juncaceae & Juncus spp. & 9 & $6.72 \pm 0.6$ & $6.37 \pm 0.3$ & ND \\
\hline Lamiaceae & Mentha longifolia & 9 & $79.34 \pm 4.0$ & $86.25 \pm 3.5$ & $8.1 \pm 0.3$ \\
\hline Malvaceae & Althaea officinalis & 4 & $7.23 \pm 0.3$ & ND & ND \\
\hline Poaceae & Triticum aestivum & 6 & $24.90 \pm 0.5$ & ND & $2.52 \pm 0.02$ \\
\hline Ranunculaceae & Ranunculus arvensis & 7 & $6.22 \pm 0.6$ & $9.62 \pm 0.5$ & ND \\
\hline
\end{tabular}

$*$ Mean $\pm \mathrm{SE} ; \mathrm{ND}=$ Not Detectable; $\quad(\mathrm{A}=$ Aliabad, $\mathrm{B}=$ Ebrahimabad, $\mathrm{C}=$ Najafabad $)$

soil As concentrations in plant species Aliabad, Ebrahimabad and Najafabad (Fig. 2), with linear regression coefficients of $0.371(\mathrm{P}<0.05), 0.221(\mathrm{P}<0.05)$ and $0.026(\mathrm{P}<0.01)$, respectively.

The arsenic transfer coefficient (AsTC) is defined as the shoot As (mg/kg dry wt) to total soil As (mg/kg dry wt) concentration ratio. In this study, AsTCs were in the ranges of 0.002-0.165 (Fig. 3).

The occurrence of high concentrations of arsenic (As), one of the most hazardous chemical elements in drinking water has been recognized, over the past two or three decades, as a great public health concern in several parts of the world (Mukherjee et al., 2006; Urík et al., 2009). Seventy five percent of the samples taken from the wells in the study areas contained As at concentrations higher than $100 \mu \mathrm{g} / \mathrm{L}$ (Table 1), greatly exceeding the maximum allowed limit for drinking waters (50 $\mu \mathrm{g} / \mathrm{L})$ (USEPA, 1980; WHO, 1993 and 1996).
Natural contamination of surface waters with As, has been recognized before in some villages in Bijar and Qorveh districts (Mosaferi et al., 2003). The accumulation of trace elements in environmental samples (soil, sediment, water, biota, etc.) is a potential risk to human health owing to presence at excessive concentrations in drinking water, or their uptake by plants and subsequent introduction into the food chain (Davis et al., 2001).

Findings of this study (unpublished data) indicate that people in the Kurdistan Province may be overexposed not only to As, but also to $\mathrm{NO}_{3}^{-}, \mathrm{Mn}$ and $\mathrm{S}$ from groundwater. Adverse health effects that may manifest in the coming years are a serious concern for the local population. The data reported here is used to compare As concentration in the main plant groups that have naturally grown on As-contaminated areas. These data are important regarding assessment of the 
'risk' that natural processes may pose to the environment in contaminated area.

The mean total As concentration in the soil ranged from 180 to $270 \mathrm{mg} / \mathrm{kg}$ in area C to 1050 to $1500 \mathrm{mg} / \mathrm{kg}$ in area B. At all the sites sampled in this study, the mean As concentrations were higher than the average toxicity threshold of $40 \mathrm{mg} / \mathrm{kg}$ established for agricultural soil (Sheppard, 1992). In soils, the bioavailability and toxicity of As and other metals are dependent on various soil parameters. Soil factors play an important role in As accumulation by plants, but their effects differ from species to species (Marin et al., 1993; Davis et al., 2001). In the areas under study here, it is the regular use of As contaminated groundwater for irrigation of agricultural land that contaminates the soil and agricultural products, potentially leading to human intake of As.

In some of the plants studied here the As concentrations are higher than the general background concentrations in plants [none detectable to $5 \mathrm{mg} / \mathrm{kg}$ dry weight] (Otte et al., 1990). The plant bioconcentration data shows that there is little relationship between the total As concentration of the soil and the soil-plant transfer coefficient.

Comparing the As concentration in the selected plants of this study with those sampled at mining sites with higher soil As concentrations (de Koe 1994; Bech et al., 1997; Madejo'n et al., 2002), the bioconcentration is found to be much lower maximum values (from less than one-half to less than one-tenth). Since As concentrations in the soils of study area were also lower, this is consistent with the idea that the soil to plant As transfer coefficient are more or less

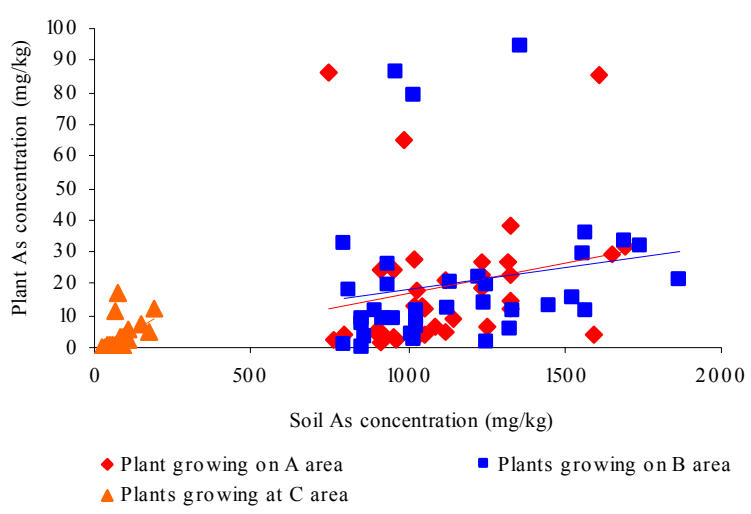

Fig. 2: Shoot As concentrations plotted against total soil As concentrations $(0-10 \mathrm{~cm})$ for samples from three contaminated areas in Bijar County independent of the soil As concentrations. Alternatively, since the authors of this study sampled only13 plant species, the authors might have missed a more strongly accumulating species by chance.

It is well known that arsenate enters plant roots via the phosphate uptake system. Both ions are taken into plant roots by a common carrier; however this phosphate/arsenate plasma membrane carrier has a much greater affinity for phosphate than arsenate. Phosphate is reported to be an efficient competitive inhibitor of arsenate uptake (Meharg and Macnair, 1990). The 3 soils investigated here had normal and similar $\mathrm{P}$ concentrations and it seems that soil $\mathrm{P}$ did not significantly interfere with plant As uptake at any of these sites. In general, As uptake by plants is largely dependent on the source, chemical speciation, pedological factors $(\mathrm{pH}, \mathrm{Eh}$, organic matter and colloid contents, soil texture, minerals and drainage conditions), plant species, age and part of plants (Otte et al., 1990; Casado et al., 2007: Singh et al., 2007). Yet in this study, these factors had no apparent influence.

Concerns have been expressed regarding potential food chain transfer of soil As via plant uptake (Lombi and Nolan, 2005). Reported soil-plant transfer coefficients for As are in the range of 0.01-0.1, considerably lower than for many other elements. The arsenic transfer coefficient (AsTC) is defined as the shoot As (mg/kg dry wt) to total soil As (mg/kg dry wt) concentration ratio. It can be used to assess the As bioaccumulation capacity of plants. The AsTCs in this study ranged from 0.002 to 0.16 with the a mean value of 0.016 in area A(Fig. 3) and mean values of 0.017 and 0.025 in areas $B$ and $C$ respectively (Fig. 3). These values

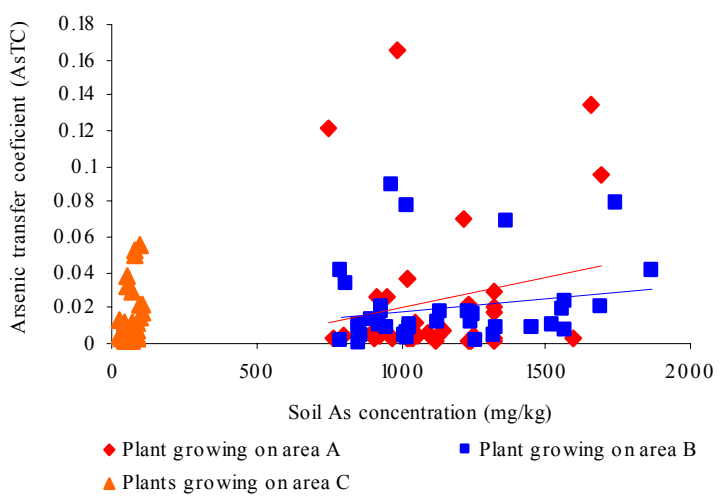

Fig. 3: Soil-plant transfer coefficients (AsTC) plotted against total soil As concentrations $(0-10 \mathrm{~cm})$ for samples from 3 contaminated areas in Bijar County 
fall well within the typical range for non-polluted soils (Sheppard, 1992), despite the presence of elevated soil As.

This strongly suggests a very low soil-plant transfer of As that is independent of both soil As concentration and soil As source. This was especially evident for the most common crop species (wheat) and in common wild herbs (Achillea millefolium). However, there is considerable variation among species regarding their AsTC values. Among all plant samples, Mentha longifolia was a particularly effective foliar accumulator of As. Therefore, its potential use as a phytoremediator should be assessed.

\section{CONCLUSION}

Tissues of the 13 plant species generally exhibited an As content positively correlated to that of the soil. The soil levels of organic matter, $\mathrm{P}, \mathrm{pH}$ and texture had no effect on soil As content and its bioavailability to plant. The As content in plants was always low, even in the most contaminated conditions, with three exceptions: Mentha. longifolia, Astragalus spp and Medicago sativa. In spite of the long contamination history of the surveyed areas, there is an evident lack of effective pressure toward As tolerance by the plant species through accumulation of the element. This means that it is likely that plants play a minor role in superficial geochemical cycling of arsenic. Nevertheless, the arsenic levels above the legal limits in agricultural soils suggest that a wider survey of As contents in crops, fodders and vegetables should be carried out.

\section{ACKNOWLEDGEMENTS}

This research was financially supported by Iranian Academic Center for Education Culture and Research ,(Grant Number1486.11).

\section{REFERENCES}

Abdel-Ghani, N. T.; Elchaghaby, G. A., (2007). Influence of operating conditions on the removal of $\mathrm{Cu}, \mathrm{Zn}, \mathrm{Cd}$ and $\mathrm{Pb}$ ions from wastewater by adsorption. Int. J. Environ. Sci. Tech., 4 (4), 451-456 (6 pages).

Abdel-Ghani, N. T.; Hegazy, A. K.; El-Chaghaby, G. A., (2009). Typha domingensis leaf powder for decontamination of aluminium, iron, zinc and lead: Biosorption kinetics and equilibrium modeling. Int. J. Environ. Sci. Tech., 6 (2), 243 248 (6 pages).

APHA; AWWA; WEF, (1992). Standard methods for the examination of water and wastewater. 18th edition. American Public Health Association, American Water Works Association and the Water Environment Federation. Washington DC., USA.
Ashworth, J.; Keyes, D.; Kirk, R.; Lessard, R., (2001). Sthandard procedure in the hydrometer method for particle size analysis. Commun. Soil Sci. Plant, 32, 633-642 (10 pages).

Babel, S.; Opiso, E. M., (2007). Removal of Cr from synthetic wastewater by sorption into volcanic ash soil. Int. J. Environ. Sci. Tech., 4 (1), 99-108 (10 pages).

Bech, J.; Poschenrieder, C.; Llugany, M.; Barcel, J.; Tume, P.; Tobias, F. J.; Barranzuela, J. L.; Va'squez, E. R., (1997). Arsenic and heavy metal contamination of soil and vegetation around a copper mine in Northern Peru. Sci. Total Environ., 203 (1), 83-91 (9 pages).

Casado, M.; Anawar, H. M.; Garica-Sanchez, A.; Santa, R. I., (2007). Arsenic bioavilability in polluted mining soil and uptake by tolerant plants (EI Caboaco mine, Spain). Bull. Environ. Contamin. Toxicol., 79 (1), 29-35 (7 pages).

Davis, A.; Sherwin, D.; Ditmars, R.; Hoenke, K. A., (2001). An analysis of soil arsenic records of decision. Environ. Sci. Tech., 35 (12), 2401-2406 (6 pages).

de Koe, T., (1994). Agrostis castellana and agrostis delicatula on heavy metal and arsenic enriched sites in NE Portugal., Sci. Total Environ., 145 (1-2), 103-109 (7 pages).

Duker, A. A.; Carranza, E. J.; Hale, M., (2005). Arsenic geochemistry and health. Environ. Int., 31 (5), 631-641 (11 pages).

Feng, X. D.; Huang, W. L.; Yang, C.; Dang, Z., (2009). Chemical speciation of fine particle bound trace metals. Int. J. Environ. Sci. Tech., 6 (3), 337-346 (10 pages).

Goyal, P.; Sharma, P.; Srivastava, S.; Srivastava, M. M., (2008). Saraca indica leaf powder for decontamination of $\mathrm{Pb}$ : Removal, recovery, adsorbent characterization and equilibrium modeling. Int. J. Environ. Sci. Tech., 5 (1), $27-$ 34 ( 8 pages).

Hughes, M. F., (2002). Arsenic toxicity and potential mechanisms of action. Toxicol. Lett., 133 (1), 1-16 (16 pages).

Jack, C. N.; Wang, J.; Shraim, A. A., (2003). Global health problem caused by arsenic from natural sources. Chemosphere, 52 (9), 1353-1359 (7 pages).

Jain, C. K.; Ali, I., (2000). Arsenic: Occurrence toxicity and speciation techniques. Water Resour., 34 (17), 4304-4312 (9 pages).

Karimi, N.; Ghaderian, S. M.; Maroofi, H.; Schat. H., (2010). Analysis of arsenic in soil and vegetation of a contaminated area in Zarshuran, Iran. Int. J. Phytoremediat., 12, 159173 (15 pages).

Kazia, T. G.; Araina, M. B.; Baig, J. A.; Jamali, M. K.; Afridi, H. I.; Jalbani, N.; Sarfraz, R. A.; Shah, A. Q.; Niaza, A., (2009). The correlation of arsenic levels in drinking water with the biological samples of skin disorders. Sci. Total Environ., 407, 1019-1026 (8 pages).

Lombi, E.; Nolan, A. L., (2005). Metal and arsenic bioavailability and uptake by hyperaccumulator plants. In: Shtangeeva, I. (Ed.), Trace and ultratrace elements in plant and soil. WIT press., Boston, Southampton.

Madejo'n, P.; Murillo, J. M.; Maraño'n, T.; Cabrera, F.; Lo'pez, R., (2002). Bioaccumulation of $\mathrm{As}, \mathrm{Cd}, \mathrm{Cu}, \mathrm{Fe}$ and $\mathrm{Pb}$ in wild grasses affected by the Aznalco' llar mine spill (SW Spain). Sci. Total Environ., 290 (1-3), 105-120 (16 pages).

Mahzuz, H. M. A.; Alam, R.; Alam, N. M.; Basak, R.; Islam, S. M., (2009). Use of arsenic contaminated sludge in making ornamental bricks. Int. J. Environ. Sci. Tech., 6 (2), 291 298 (8 pages). 
Malakootian, M.; Nouri, J.; Hossaini, H., (2009). Removal of heavy metals from paint industry's wastewater using Leca as an available adsorbent. Int. J. Environ. Sci. Tech., 6 (2), 183-190 (8 pages).

Marin, A. R.; Masschenlyn, P. H.; Patrick, W. H., (1993). Soil redox $/ \mathrm{pH}$ stability of arsenic species and its influence on arsenic uptake by rice. Plant Soil, 152 (2), 245-253 (9 pages).

Meharg, A. A.; Jardine, L., (2003). Arsenite transport into paddy rice (Oryza sativa) roots. New Phytol., 157 (1), 39-44 (6 pages).

Meharg, A. A.; Macnair, M. R., (1990). An altered phosphate uptake system in arsenate-tolerant Holcus lanatus L. New Phytol., 116 (1), 29-35 (7 pages).

Mosaferi, M.; Yunesian, M.; Mesdaghinia, A. R.; Nadim, A.; Nasseri, S.; Mahvi, A. H., (2003). Occurrence of arsenic in Kurdistan Province of Iran. In BUET-UNU international symposium, international training network center. Dhaka, Bangladesh. Tokyou.

Mosaferi, M.; Yunesian, M.; Mesdaghinia, A. R.; Nasseri, S.; Mahvi, A. H.; Nadim, H., (2005). Correlation between arsenic concentration of drinking water and hair. Iran J. Environ. Health Sci. Eng., 2, 11-23 (13 pages).

Mosaferi, M.; Yunesian, M.; Dastgiri, S.; Mesdaghiniad, A.; Esmailnasab, N., (2009). Prevalence of skin lesions and exposure to arsenic in drinking water in Iran. Sci. Total Environ., 390 (1), 69-76 (8 pages).

Mukherjee, A.; Sengupta, M. K.; Hossain, M. A.; Ahamed, S.; Das, B.; Nayak, B.; Lodh D.; Rahman M. M.; Chakraborti D., (2006). Arsenic contamination in groundwater: a global perspective with emphasis on the Asian scenario. J. Health Popul. Nutr., 24 (2), 142-163 (22 pages).

Okafor, E. C.; Opuene, K., (2007). Preliminary assessment of trace metals and polycyclic aromatic hydrocarbons in the sediments. Int. J. Environ. Sci. Tech., 4 (2), 233-240 (8 pages).

Olsen, S. R.; Cole, C. V.; Watanabe, F. S.; Dean, L. A., (1954). Estimation of available phosphorus in soils by extraction with sodium bicarbonate. Circular, US: Department of Agriculture, 939.

Otte, M. L.; Rozema, J.; Beek, M. A.; Kater, B. J.; Broekman, R. A., (1990). Uptake of arsenic by estuarine plants and interactions with phosphate, in the field (Rhine Estuary) and under outdoor experimental conditions. Sci. Total Environ., 97-98, 839-854 (16 pages).

Reza, R.; Singh, G.; (2010). Heavy metal contamination and its indexing approach for river water. Int. J. Environ. Sci. Tech., 7 (4), 785-792 (8 pages).
Samarghandi, M. R.; Nouri, J.; Mesdaghinia, A. R.; Mahvi, A. H.; Nasseri, S.; Vaezi, F., (2007). Efficiency removal of phenol, lead and cadmium by means of $\mathrm{UV} / \mathrm{TiO} 2 / \mathrm{H} 2 \mathrm{O} 2$ processes. Int. J. Environ. Sci. Tech., 4 (1), 19-26 (8 pages).

Singh, S. K.; Juwarkar, A. A.; Kumar; S., Meshram, J.; Fan, M., (2007). Effect of amendment on phytoextraction of arsenic by Vetiveria Zizanioides from soil. Int. J. Environ. Sci. Tech., 4 (3), 339-344 (6 pages).

Sheppard, S. C., (1992). Summary of phytotoxic levels of soil arsenic. Water Air Soil Pollut., 64 (3-4), 539-550 (12 pages).

Soon, Y. K.; Abboud, S., (1991). A comparison of some methods for soil organic carbon determination. Commun. Soil Sci. Plant Anal., 22 (9-10), 943-954 (12 pages).

Urík, M.; Littera, P.; Ševc, J.; Kolenčík, M.; Čerňanský, S., (2009). Removal of arsenic (V) from aqueous solutions using chemically modified sawdust of spruce (Picea abies): Kinetics and isotherm studies. Int. J. Environ. Sci. Tech., 6 (3), 451-456 (6 pages).

USEP, (1980). Water Quality Criteria Documents, Availability. United States Environmental Protection Agency. Part V, Federal Register, 45, 79318-79379 (62 pages).

Vasanthavigar, M.; Srinivasamoorthy, K.; Vijayaragavan, K.; Rajiv, G. R.; Chidambaram, S.; Sarama, V. S.; Anandhan, P.; Manivannan, R.; Vasudevan, S., (2010). Application of water quality index for groundwater quality assessment: Thirumanimuttar sub-basin, Tamilnadu, India. Environ. Monitor. Assess., 171 (1-4), 595-609 (15 pages).

Villa-Lojo, M. C.; Rodriguez, E.; Mahia, P. L.; Mnuiategui, M. S.; Rodriguez, D. P., (2002). Coupled high performance liquid chromatography-microwave digestion-hydride generation-atomic absorption spectrometry for inorganic and organic arsenic speciation in fish tissue. Talanta., 57 (4), 741-775 (35 pages).

Warren, G. P.; Alloway, B. J.; Lepp, N. W.; Singh, B.; Bochereau, F. J. M.; Penny, C., (2003). Field trials to assess the uptake of arsenic by vegetables from contaminated soils and soil remediation with iron oxides. Sci. Total Environ., 311 (1-3), 19-33 (15 pages).

WHO, (1993). Guidelines for drinking water quality recommendations. In: World Health Organization, guidelines for drinking-water quality, $2^{\text {nd }}, 2$, Geneva.

WHO, (1996). Health criteria and other supporting information. In: World Health Organization, Guidelines for drinking-water quality, $2^{\text {nd }}, 2$, Geneva.

\footnotetext{
AUTHOR (S) BIOSKETCHES

Zandsalimi, S., M.Sc., Researcher, Iranian academic center for education culture and research (iacecr)- Kurdistan, Iran. E-mail: s_zandsalimi@yahoo.com

Karimi, N., Ph.D., Assistant Professor, Laboratory of plant physiology, Department of Biology, Faculty of Science, Razi University, Kermanshah, Iran. E-mail: nkarimie@yahoo.com

Kohandel, A., Ph.D., Academic staff, Iranian academic center for education culture and research (iacecr), Tehran, Iran 14155-4364. E-mail:kohandel_co@yahoo.com

How to cite this article: (Harvard style)

Zandsalimi, S.; Karimi, N.; Kohandel, A., (2011). Arsenic in soil, vegetation and water of a contaminated region. Int. J. Environ. Sci. Tech., 8 (2), 331-338.
} 